\title{
Selection of high-yielding pea varieties in the conditions of the Cis-Ural steppe zone of the Bashkortostan Republic
}

\author{
Firzinat Davletov ${ }^{1, *}$, Karina Gainullina ${ }^{1,2}$ \\ ${ }^{1}$ Ufa Federal Research Center of the Russian Academy of Sciences, Bashkir Research Institute of \\ Agriculture, Ufa, Russia \\ ${ }^{2}$ The Institute of Biochemistry and Genetics - a separate structural unit of the Ufa Federal Research \\ Center of the Russian Academy of Sciences, Ufa, Russia
}

\begin{abstract}
Peas have become the most important leguminous crop worldwide. Large areas in Russia are used for pea growing. Unfavourable weather and climatic conditions often lead to a significant yield decline. There is an urgent need to develop new high-yielding varieties adapted to local conditions. The current paper presents the results of long-term breeding of modern pea cultivars Chishminsky 229, Pamiati Hangildina, Pamiati Popova, meeting the requirements of agricultural production. The research was conducted in the Bashkir Agricultural Research Institute. The varieties were bred by repeated single selection based on intervariety hybridization. Chishminsky 229 and Pamiati Hangildina cultivars are included in the State Register of Breeding Achievements. Pamiati Popova is currently undergoing state variety testing. According to the comparative testing in 2016-2020, the excess yield compared to Chishminsky 95 standard variety was $2.1 \mathrm{c} / \mathrm{ha}$ for Chishminsky 229 variety, $1.9 \mathrm{c} / \mathrm{ha}$ for Pamiati Hangildina cultivar, and $3.2 \mathrm{c} /$ ha for Pamiati Popova cultivar.
\end{abstract}

\section{Introduction}

Field pea is the most important leguminous crop of the temperate zone of the Earth $[1,2]$. According to the Food and Agriculture Organization of the United Nations (FAO), Russia, along with Canada and China, is the world leader in the production of pea grain. The crop is cultivated widely in the country. It is unpretentious to the conditions of cultivation. In the north of the Russian Federation, peas grow in the circumpolar region. Its western, eastern and southern cultivation boundaries coincide with the country's borders. The pea altitudinal limits reaches $2400 \mathrm{~m}$ above sea level [3]. These advantages make it possible to cultivate peas in large areas compared to soy, grown mainly in the south of Russia. The largest areas under peas are concentrated in the Middle Volga region, Tatarstan, Bashkortostan, and the Central Chernozem soil zone [4]. Since a significant part of the Russian territory is located in natural zones of high latitudes, experts claim that a changing climate can make peas the main crop that ensure food security in the country in the years to come 5].

\footnotetext{
*Corresponding author: sci_secr_bniish@bk.ru
} 
Peas are used as a food crop (as grain, green peas), feed (both as green feed, and for hay, haylage, silage, grain fodder and hay flour production), green manuring [6, 7]. However, peas are a valuable high-protein crop of great importance for addressing the protein issue in crop production. Pea seeds are rich in protein, reaching $36 \%$, starch, fibre, vitamins $\mathrm{A}, \mathrm{B}, \mathrm{B}_{2}, \mathrm{C}$ and mineral salts necessary for human and animal nutrition $[8,9]$. Introducing peas into farm animals' fodder contributes to the higher output of livestock products at lower costs [10]. In the Cis-Ural steppe zone conditions, pea seeds contain 22$26 \%$ protein, which is 2 times more than cereals.

Peas interact with nodule bacteria and fix nitrogen accumulating it in the soil up to 70$80 \mathrm{~kg}$ per 1 ha and providing high yields of grain and green mass without applying nitrogen fertilizers. The studied crop is a good precursor for winter and spring cereals and industrial crops [11]. With proper agricultural technology, the yield of pea hay ranges from 30 to 60 c/ha, green mass from 220 to $260 \mathrm{c} /$ ha, grain up to $45 \mathrm{c} /$ ha (on average $20-25 \mathrm{c} / \mathrm{ha}$ ).

The natural and climatic conditions of the Cis-Ural steppe zone of Bashkortostan favour high yields of this valuable high-protein crop. People began to cultivate peas in the Ufa province territory from the first half of the nineteenth century [12]. In the Soviet period, the Bashkir ASSR's pea acreage was maximum and increased to 300 thousand hectares by the 1970s [13]. At that time, the republic led the country in terms of pea grain production. However, the areas under peas both in the country and the republic suffered a big reduction during perestroika in the second half of the 80 s-early 90 s. Today peas occupy about 60 thousand hectares in the Republic of Bashkortostan [14]. There is an urgent need for increased production of this valuable crop and overcome protein deficiency in foodstuff and fodder by expanding the pea area in Bashkortostan. In addition, it is essential to improve the cultivation technology of the varieties available and change varieties timely. Most of the cultivated pea varieties of foreign (domestic) selection are poorly adapted to the soil and climatic conditions of the Cis-Ural steppe zone. So far a key issue is developing new highyielding varieties of local selection, maximally adapted to cultivation in the Republic of Bashkortostan [15-16].

\section{Materials and methods}

Selection experiments were set up and conducted in the fields of the Chishminsky Breeding Center for Crop Production of the Bashkir Agricultural Research Institute 2005-2020.

The soil in the experimental plots was medium-power carbonate chernozems. The arable soil layer consisted of 8.1-8.5\% humus, 22.5-23.5 mg of phosphorus oxide, $0.3-0.5 \%$ of total nitrogen, $41.5-42.0 \mathrm{mg}$ mobile potassium per $100 \mathrm{~g}$ of the soil. The calcium content in the arable horizon is $5.6 \%$. The soil is neutral, medium loamy-silty-sandy by its mechanical composition.

The climate of the breeding center area is continental with low moisture availability. The data provided by the Chishmy agricultural weather station indicates that precipitation over the research years ranged from 220 to $560 \mathrm{~mm}$ and averaged $390 \mathrm{~mm}$, being $188 \mathrm{~mm}$ during the pea growing season from May to August. The frost-free period lasts 115 days. The average sum of active temperatures was equal to $2228^{\circ} \mathrm{C}$.

Peas were sown with soil ripeness in late April-early May. The predecessor is winter grain crops. The pea selection was performed by repeated single selection based on intervariety hybridization.

For hybridization, plants with well-developed, typical for the variety traits were selected. Emasculation was performed in the bud phase since the flower reproductive organs mature before its opening. Anthers were removed from flowers of the first and second layers where most beans develop. The keel in female plant flowers was cut with a 
sharp needle, and all the stamens were removed with tweezers. The emasculated flowers were placed in insulators made of parchment paper.

Pollination was carried out as the stigma matured when the corolla took the shape corresponding to the opened flower. If during emasculation the weather was hot dry, the flowers were pollinated on the same day. In cool cloudy weather, the stigma matures later, and pollination was carried out after 1-2 days. The neutered flowers were pollinated by transferring mature pollen from the paternal plant to the stigma with a brush or tweezers.

The study of hybrids and the selection of elite plants was carried out by the pedigree method, starting from $F_{2}$, until constant lines were obtained. Setting up selection experiments, grain yield recording, analysis of the yield structure was carried out in accordance with the methodology of the Russian State Commission for Variety Testing of agricultural crops [17], statistical analysis of experimental data according to B.A. Dospekhov [18].

\section{The results and discussion}

Pea breeding has been carried out in the Bashkir Agricultural Research Institute since 1938. During this period, breeders have created a diverse source and breeding material and developed 27 varieties of peas. The most widespread pea varieties of recent years are Chishminsky 95, Chishminsky 229, Pamiati Hangildina. In 2019, a new cultivar named Pamiati Popova was submitted for state testing.

High-yielding pea variety Chishminsky 229 was created by repeated single selection from a hybrid combination obtained by crossing local selection cultivar Chishminsky 75, characterized by medium-sized non-shattering seeds, with foreign (domestic) selection Zelenozerny 1 variety (Voronezh region), bearing a seed shattering trait. The parent components were distinguished by a large number of seeds in the bean and per plant. Female and male forms differed significantly in economic and biological characteristics between themselves and variety Chishminsky standard 95.

When creating Chishminsky 229 variety, parent pairs for hybridization were selected based on contrasting traits. First of all, characteristics directly related to the yield and a high heritability coefficient were considered as the number of beans, seeds per plant, the size of the seeds. Genetic distance "seed size" of parental varieties was equal to -9 , "the number of beans per plant" and "the number of seeds from per plant" - 2.0 and 4.8, respectively. These data indicate significant differences in the varieties Chishminsky 75 and Zelenozerny 1 according to these traits.

Hybridization was carried out in the field. 30 flowers were crossed, 15 beans and 55 seeds were obtained. The $F_{1}$ hybrid seeds were sown in a greenhouse. Elite plants from the second generation hybrids were selected by the number of productive nodes and seed nonshattering. These traits are recessive in nature and less changeable. The $\mathrm{F}_{2}$ hybridproductivity was evaluated by the number of beans and seeds per plant. Parent elite plants in the third generation hybrids were selected based on the seed content, number and weight per plant (Table 1).

Table 1. Productivity indicators of elite parent plants selected for breeding pea variety Chishminsky 229.

\begin{tabular}{|c|c|c|c|c|c|}
\hline & & \multicolumn{2}{|c|}{ The number, pcs. } & \multirow{2}{*}{$\begin{array}{c}\text { Seed weight } \\
\text { per plant, g }\end{array}$} \\
\cline { 3 - 5 } $\begin{array}{c}\text { Hybrid combination, } \\
\text { generation }\end{array}$ & $\begin{array}{c}\text { Selection } \\
\text { variant }\end{array}$ & beans per plant & $\begin{array}{c}\text { seeds in } \\
\text { a bean }\end{array}$ & $\begin{array}{c}\text { seeds per } \\
\text { plant }\end{array}$ & \\
\cline { 3 - 5 } & &
\end{tabular}




\begin{tabular}{|c|c|c|c|c|c|}
\hline $\begin{array}{c}\text { Chishminsky 75 } \times \\
\text { Zelenozerny 1, } \mathrm{F}_{3}\end{array}$ & single & 3.0 & 4.0 & 12.0 & 3.8 \\
\hline $\begin{array}{c}\text { Chishminsky 75 } \times \\
\text { Zelenozerny 1, } \mathrm{F}_{3}\end{array}$ & bulk & 5.0 & 3.0 & 14.0 & 3.9 \\
\hline
\end{tabular}

Subsequently, there were no differences in the crop structure between the hybrids of the fourth generation with shattering and non-shattering seeds. A single selection in the second and third generations of hybrids identified highly productive forms with non-shattering seeds.

The constant seed is selected in $\mathrm{F}_{5}$. The breeding material isolated from the hybrid nursery was evaluated in the breeding and control nurseries, then studied in preliminary and competitive variety tests. The test results showed higher seed yields of the new line being $2.8 \mathrm{c} / \mathrm{ha}$ in the control nursery, $4.0 \mathrm{c} / \mathrm{ha}$ in the preliminary variety testing, $3.2 \mathrm{c} / \mathrm{ha}$ in the competitive variety testing on average for 7 years.

Chishminsky 229 leafed belongs to the ecaducum variety. The growing season ranges from 65 to 75 days. The height of the plant is $60-90 \mathrm{~cm}$. There are 13-14 unproductive nodes, 2-3 productive nodes. The beans are straight with a blunt tip. The seeds are yellow, rounded, the seedpod fuses with the seed peel (Figure 1).

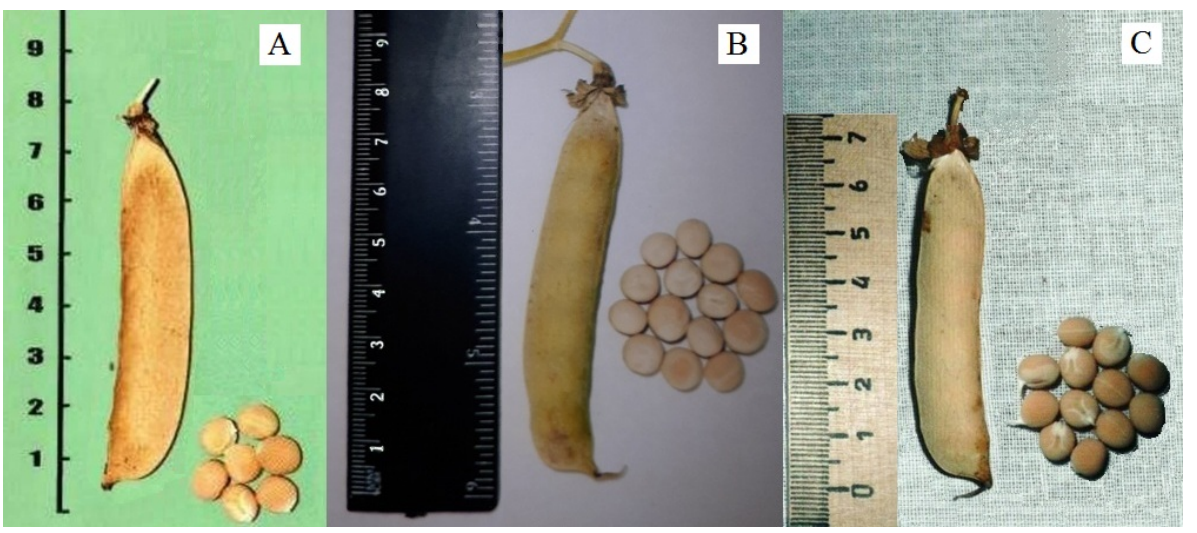

Fig. 1. Beans and pea seeds: A- variety Chishminsky 229, B - variety Pamiati Hangildina, C - variety Pamiati Popova.

The variety is characterized by a high weight of 1000 seeds (230-270 g) and a valuable grain quality. The seeds contain from 24 to $28 \%$ protein.

In the conditions of the Cis-Ural steppe zone of the Bashkortostan Republic, pea variety Chishminsky 229 produced the highest yield (40 c/ha) in the Diurtiulinsky district. On average, in 2016-2020, the competitive variety testing demonstrated the excess at $2.1 \mathrm{c} / \mathrm{ha}$ over the standard variety Chishminsky 95 (Table 2).

Since 2007, the variety has been included in the State Register of Breeding Achievements approved for Use in the Ural and Central Chernozem regions of the Russian Federation.

The high-tech leafless pea variety Pamiati Hangildina was created by intravariety hybridization between the leafed variety of local selection Chishminsky 95 growing rapidly in the initial phases of development, and tendriled variety of foreign selection Usach (Ukraine). Parents for crossing were selected based on contrasting characteristics, taking into account the seed content, size, and number per plant. The crop structure analysis showed that parents are characterized by large seeds, a high number per plant, and high productivity. 20 flowers were crossed, 3 beans and 6 seeds were obtained. 
Table 2. The results of the competitive testing of pea varieties for 2016-2020.

\begin{tabular}{|c|c|c|c|c|c|}
\hline \multirow{2}{*}{ Name of varieties } & \multicolumn{2}{|c|}{ Period, days } & \multirow{2}{*}{$\begin{array}{c}\text { Weight } \\
\text { of } 1000 \\
\text { seeds, } g\end{array}$} & $\begin{array}{c}\text { Seed } \\
\text { yield, } \\
\text { c/ha }\end{array}$ & $\begin{array}{c}\text { Deviation } \\
\text { from the } \\
\text { standard, } \pm \\
\text { c/ha }\end{array}$ \\
\hline flowering & $\begin{array}{c}\text { shoots- } \\
\text { ripening }\end{array}$ & 68 & 220 & 20.8 & - \\
\hline Chishminsky 95 & 38 & 70 & 230 & 22.9 & +2.1 \\
\hline Chishminsky 229 & 40 & 68 & 220 & 22.7 & +1.9 \\
\hline Pamiati Hangildina & 37 & 71 & 195 & 24.0 & +3.2 \\
\hline Pamiati Popova & 40 & - & - & 1.65 & - \\
\hline HCP05 & - & - & & \\
\hline
\end{tabular}

In the autumn-winter period, $\mathrm{F}_{1 \text { hybrids }}$ were propagated in a greenhouse. Seeds collected from hybrid plants of the first generation were sown in the field. $\mathrm{F}_{2}$ hybrid phenology was examined during the growing season. The best parents were selected based on "the bean number per plant". The final assessment was carried by "the seed number per plant". Additionally, elite plants were selected by the seed content, size, non-shattering and leaf type.

The second generation demonstrated a rapid growth process. Morphological and economically valuable features varied greatly. Thus, $\mathrm{F}_{2}$ plants included 65 varieties with common leaves and 19 with tendrils, close to the ratio of $3: 1$.

The seed productivity analysis of tendriled (leafless) and common (leafed) crops showed that the first ones had lower productivity ( $8.07 \mathrm{~g}$ seed weight per plant-)compared with the latter (9.17 g seed weight per plant). Leafed morphotypes developed high productivity due to the greater number of beans and seeds per plant. The conducted research revealed that common (leafed) peas had an average of 5.6 beans and 29.2 seeds per plant, while tendriled (leafless) had 5.0 beans and 24.7 seeds. A total of 27 plants were distinguished in the second-generation hybrids, of which 7 were leafless morphotypes.

The offspring of elite $\mathrm{F}_{2}$ plants were sown in a field in a hybrid nursery. Repeated selections were carried by "seed content", "seed size", and "seed weight per plant". The offspring of the selected plants were sown in the field in families, without repetitions. For the subsequent breeding work, elite plants were selected from the hybrids of the fourth generation. They were characterized by the highest seed number per plant and had a larger seed size (Table 3 ).

Table 3. The crop structure indicators of parent plants selected for breeding cultivar Pamiati Hangildina.

\begin{tabular}{|c|c|c|c|c|c|}
\hline \multirow{2}{*}{$\begin{array}{c}\text { Hybrid combination, } \\
\text { generation }\end{array}$} & \multicolumn{3}{|c|}{ The number, pcs. } & \multirow{2}{*}{$\begin{array}{c}\text { Seed weight } \\
\text { per plant, g }\end{array}$} \\
\cline { 3 - 5 } & fruit & $\begin{array}{c}\text { beans per } \\
\text { plant }\end{array}$ & $\begin{array}{c}\text { seeds in a } \\
\text { bean }\end{array}$ & $\begin{array}{c}\text { seeds per } \\
\text { plant }\end{array}$ & \\
\hline $\begin{array}{c}\text { population } \\
\text { Chishminsky 95 } \\
\text { Usach, F4 }\end{array}$ & 1.9 & 2.6 & 4.1 & 10.6 & 2.72 \\
\hline $\begin{array}{c}\text { elite plants } \\
\text { Chishminsky 95 } \\
\text { Usach, } \text { F }_{4}\end{array}$ & 2.0 & 3.0 & 4.0 & 12.0 & 3.09 \\
\hline
\end{tabular}

The constant form was bred in $\mathrm{F}_{5}$. The subsequent study of the breeding material isolated from the hybrid nursery was carried out in the breeding and control nurseries, then 
in the preliminary and competitive variety tests. The new line had a higher yield of $3.1 \mathrm{c} / \mathrm{ha}$ in the preliminary variety testing and $6.7 \mathrm{c} / \mathrm{ha}$ in the competitive variety testing on average for 5 years.

Cultivar Pamiati Hangildina belongs to the zirrosum variety. Tendrils help plants connect tightly that makes them resistant to lodging. The stem height is $50-80 \mathrm{~cm}$. This variety of plants have large semi-heart-shaped stipules. There are 12-13 unproductive nodes, 2 productive ones. There are 2 flowers in the brush. The flowers are white in color and large in size. The bean seed content is 4-5 seeds. The seeds are round-shaped, differ in alignment. Cotyledons are yellow. The seed stalk fuses with the seed peel (Figure 1).

The variety is early-season, drought-tolerant, medium-resistant to diseases and pests. The period from emergence to full ripeness ranges from 60 to 69 days. It has a high weight of 1000 seeds $(220-270 \mathrm{~g})$. The protein content in cultivar Pamiati Hangildina is at the standard level and is $22-24 \%$.

The yield is high. According to the competitive variety testing conducted in 2016-2020, Pamiati Hangildina exceeded the seed yield of a standard variety Chishminsky 95 by 1.9 $\mathrm{c} /$ ha (Table 2 ). The highest yield of the variety reaches $42-43 \mathrm{c} / \mathrm{ha}$.

It has been included in the State Register of Breeding Achievements with admission to use in the Volga-Vyatka, Middle Volga and Ural regions of the Russian Federation since 2012.

To breed a new variety Pamiati Popova, the method of repeated single-family selection was used. Intravariety crossing of a leafed sample of foreign selection K-7992 (Korea) from the All-Russian Institute of Plant Breeding, distinguished by a large number of seeds in a bean, with a leafless variety of foreign selection Usach (Ukraine), growing rapidly in the initial phases of development produced a hybrid material for breeding early-ripening, highly productive peas of a leafless morphotype.

The parent plant was selected in 2012 and was characterized by a strong stem of $78 \mathrm{~cm}$ height and a large number of fruiting nodes $(5 \mathrm{pcs}$.). The number of beans and seeds from the plant was 9 and 38, respectively. The promising breeding material was evaluated in the selection and control nurseries, preliminary and competitive variety testing from 2013 to 2019 .

The leafless variety Pamiati Popova belongs to the botanical variety zirrosum. The period from germination to full ripeness varies from 65 to 78 days, making this cultivar medium-ripened.

Pamiati Popova plants have a lodging-resistant stem of 60 to $80 \mathrm{~cm}$ in height. Semiheart-shaped stipules are of a large size. Inflorescences are medium-sized, white in color. The number of beans per plant is 6-8. The bean seed content is 5-7 seeds. Seeds are shuttering, round-angular in shape. The cotyledon colour is yellow (Figure 1). The grain contains $21-23 \%$ protein. The seed size is average (the weight of 1000 seeds is $190-220 \mathrm{~g}$ ).

Variety Pamiati Popova is characterized by a high seed yield. Thus, the competitive variety testings in 2016-2020 showed the excess over the standard variety Chishminsky 95 at $3.2 \mathrm{c} /$ ha (Table 2). The highest yield ( $28 \mathrm{c} / \mathrm{ha}$ ) of the new variety was recorded in 2020 . Cultivar Pamiati Popova will be tested again at the state variety testing plots in 2021 .

\section{Conclusion}

Despite the success in breeding new varieties characterized by high productivity, nutritional value, improved ecological plasticity, developing new varieties and improving the existing cultivation technology remain relevant in a changing climate. One of the main challenges of breeders is producing high-yielding varieties of the highest productivity potential in different soil and climatic conditions. In recent years, the State Register of Breeding Achievements has included highly productive, valuable grain quality, adaptive to the 
conditions of the Pre-Ural steppe zone of the Bashkortostan Republic pea varieties Chishminsky 229 and Pamiati Hangildina selected by the Bashkir Agricultural Research Institute. Expanding the acreage under these varieties and introducing a new cultivar Pamiati Popova into production, will increase the economic efficiency of cultivating peas for seeds and fodder.

\section{Acknowledgements}

The study was carried out in the Seed-Breeding Center for Forage Crops of UFRC RAS" (project No. 075-15-2021-549).

\section{References}

1. P.H. Graham, C.P. Vance, Plant Physiol. 131, 872-877 (2003) DOI 10.1104/pp.017004

2. I. Kuznetsov, N. Anokhina, I. Akhmadullina, F. Safin, F. Davletov, Agronomy Research 18, 472-482 (2020) DOI 10.15159/ar.20.154

3. N.V. Shelepina, A.Y. Shchurov, Scientific notes OrelGIET 1, $537-539$ (2010) (In Russ.)

4. K.P. Gainullina, Vestnik OSAU 73, 84-77 (2018) (In Russ.)

5. O.E. Kosterin, Vavilov Journal of Genetics and Breeding 19, 13-26 (2015). (In Russ.) DOI 10.18699/VJ15.002

6. P. Smýkal, G. Aubert, J. Burstin, C.J. Coyne, N.T.H. Ellis, A.J. Flavell, R. Ford, M. Hýbl, J. Macas, P. Neumann, K.E. McPhee, R.J. Redden, D. Rubiales, J.L. Weller, T.D. Warkentin, Agronomy 2, 74-115 (2012) DOI 10.3390/agronomy2020074

7. V.I. Brezhneva, Pea breeding in the Kuban (Prosveshcheniye-Yug, Krasnodar, 2006) (In Russ.)

8. R.H. Makasheva, Cultivated flora of the USSR (Kolos, Leningrad, 1979) (In Russ.)

9. J. Burstin, P. Salloignon, M. Chabert-Martinello, J.B. Magnin-Robert, M. Siol, F. Jacquin, A. Chauveau, C. Pont, G. Aubert, C. Delaitre, C. Truntzer, G. Duc, BMC Genomics 16, 105 (2015) DOI 10.1186/s12864-015-1266-1

10. N.M. Verbitskii, Pea breeding in the North Caucasus (Lugan', Rostov-na-Donu, 1992) (In Russ.)

11. N. Tayeh, G. Aubert, M.L. Pilet-Nayel, I. Lejeune-Hénaut, T.D. Warkentin, J. Burstin, Front. Plant Sci. 6, 1037 (2015) DOI 10.3389/fpls.2015.01037

12. V.H. Hangil'din, V.V. Hangil'din, Proceedings of the Bashkir Research Institute of Agriculture 3, 40-61 (1969) (In Russ.)

13. G.V. Gulyaev, A.P. Dubinin, Selection and seed growing of field crops with the basics of genetics (Kolos, Moscow, 1980) (In Russ.)

14. F.A. Davletov, K.P. Gainullina, Agrarian Bulletin of the Urals 4, 5-6 (2011) (In Russ.)

15. F.A. Davletov, K.P. Gainullina, Vestnik BSAU 26, 10-13 (2013) (In Russ.)

16. F.A. Davletov, K.P. Gainullina, F.F. Magafurova, Vestnik OSAU 84, 72-77 (2020) (In Russ.) DOI 10.37670/2073-0853-2020-84-4-72-77

17. M.A. Fedin, Methodology of the state variety testing of agricultural crops (Moscow, 1985) (In Russ.)

18. B.A. Dospekhov, Methods of field experiment (Al'yans, Moscow, 2011) (In Russ.) 